\title{
Aleš MAVER QUI PRIMUS ROMANORUM \\ PRINCIPUM MAIESTATEM DEI \\ SINGULARIS AC VERI COGNOVISTI: \\ PABERKI O KONSTANTINOVI \\ PODOBI PRI KRŠČANSKIH \\ LATINSKIH ZGODOVINARJIH 4. \\ IN 5. STOLETJA
}

\begin{abstract}
Izvleček
Članek obravnava nekatere pomembne odlomke pri latinsko pišočih krščanskih zgodovinarjih 4 . in 5 . stoletja, ki se nanašajo na prvega krščanskega rimskega cesarja Konstantina. Avtor ugotavlja, da so se že v tem obdobju izoblikovale pomembne razlike $\mathrm{v}$ pojmovanju cesarjeve osebe med vzhodnim in zahodnim krščanstvom. Le Rufin je zvesto sledil Evzebijevemu modelu in cesarja prikazal izključno pozitivno. Vsi ostali pisci so bili do njegovega lika bolj zadržani, kar še zlasti velja za Hieronima. Laktancij po drugi strani sicer ni postavljal pod vprašaj nobenega Konstantinovega dejanja, a je svoje bralce zmedel, ko je zelo povzdignil tudi lik njegovega socesarja Licinija.
\end{abstract}

\section{Abstract}

The article discusses some major references to the first Christian emperor, Constantine the Great, found in the Christian Latin historians of the $4^{\text {th }}$ and $5^{\text {th }}$ centuries and in Augustine's De Civitate Dei. The author shows that this period already displays important differences between the Eastern and Western Christendom in the assessment of the emperor. The only writer to adopt the Eusebian model completely and represent the emperor in an entirely positive light is Rufinus. All other Christian historians have some reservations about Constantine, which is particularly true of Jerome. Lactance, on the other hand, never questions Constantine's actions, but has confused his readers by giving equal praise to his co-emperor Licinius.

PRAVDA o liku in dela cesarja Konstantina (začuda mu skoraj vsi puščajo epiteton 'Veliki', najsi bodo do njega še tako kritično razpoloženi) je na evropskem zahodu stara stvar. Vsaj od razsvetljenstva naprej je bilo nič koliko poskusov pahniti tega rimskega cesarja z zavidljivo dolgim stažem s piedestala, na katerem je bil po mnenju s stoletji vse širšega kroga dvomljivcev nezasluženo in vse preveč časa. ${ }^{1}$ Temu se je že v razsvetljenstvu pridružilo mestoma kar otročje navduševanje nad nesrečnim Konstantinovim sorodnikom Julijanom, ki bi menda lahko

1 Zelo poučno je vreči pogled na nekaj sodb o Konstantinu, zbranih pri Bleckmann 1996, 143-146. 
docela preobrnil rimsko zgodovino, ${ }^{2}$ ne glede na to, da so celo poznoantični pogani šele post festum in zaradi tegob poznejših desetletij $\mathrm{v}$ omenjenem cesarju začeli gledati obnovitelja stare rimske slave. ${ }^{3}$

Pri tem je zanimivo, da v ospredju pravde nikoli ni bil Konstantin kot tak, saj se je razprava zmeraj vrtela predvsem okoli njegovega odnosa do krščanstva, ob čemer se je nekaterim svojim kritikom zdel preveč, drugim pač premalo kristjan. V ospredje je tako vedno znova prihajalo njihovo lastno razumevanje krščanstva (kar je lepo razvidno že pri razsvetljenskih interpretacijah Konstantina), ki je imelo s cesarjevim časom malo ali nič skupnega. Kljub temu se je izraz »konstantinski preobrat « v celotnem spektru (pri tistih, ki so Konstantinu očitali, da je kapituliral pred Cerkvijo, pa tudi pri onih, ki so menili, da jo je ravno on za več kot tisočletje vpregel v voz države) docela uveljavil. Konstantin je postal neke vrste blagovna znamka, ki jo je očitno moč tudi tržiti, kot dokazuje komercialni uspeh Brownove kriminalke in z njo (tako ali drugače) povezanih (psevdo)zgodovinskih besedil, v katerih omenjeni rimski cesar nikoli ne nastopa kot polnokrvna zgodovinska oseba, marveč kot nekakšna brezoblična etiketa za določene domnevne pojave, povezane s krščansko cerkvijo.

Izkaže pa se, da se težave zahodnjakov s Konstantinovim likom niso začele šele $\mathrm{z}$ razsvetljenstvom. Že v krščanski pozni antiki v zahodnih zemljepisnih širinah nikakor ni bil deležen tolikšnega nedeljenega navdušenja kot v vzhodni polovici rimske države, kar se še danes odraža v preprostem dejstvu, da v vzhodni cerkvi cesarja častijo kot enega najpomembnejših svetnikov, medtem ko katoličani čast oltarja prisojajo samo njegovi pobožni (a v Konstantinovi družinski drami ne neproblematični $\left.{ }^{4}\right)$ materi Heleni. Razlogov za tako stanje je več in le manj pomembni med njimi se tičejo Konstantina samega.

Najprej je tu stanje zahodnih virov o njem. Medtem ko nekatera poganska pričevanja (predvsem panegiriki) pomembno dopolnjujejo njegovo zgodovinsko podobo (in so mu v zgodnejših obdobjih še dokaj naklonjena ${ }^{5}$ ), je med krščanskimi historiografskimi besedili kot vir zares uporaben Laktancijev spis De mortibus persecutorum, ki je bil spričo nekaterih svojih potez (prim. Momiglianovo sodbo o »groznem delcu« ali precej razširjeno opletanje s pojmom 'pamflet' v zvezi z njim ${ }^{6}$ )

2 Ibidem; taka sodba presenetljivo tu in tam prihaja na plan celo v odlični Demandtovi sintezi (1998).

3 Barcelo 2004, 183.

4 O njej nazadnje Brandt 2006, zlasti 118ss. in 145-149.

5 O tem npr. Winkelmann 2003, 34ss.

6 Prim. D'Elia 1980, 392; A. S. Christensen 1980; podobno Winkelmann 1990, ki ga postavlja pred vrata zgodovinopisja. 
v preteklosti najbrž celo podcenjen. ${ }^{7}$ Vsi ostali zapisi so mlajši (prvi, Hieronimov, šele iz časa okrog 380, Rufinov, Orozijev in Avguštinov pa sodijo že v 5. stoletje) in ne morejo o zgodovinskem Konstantinu povedati ničesar novega. Toliko več povedo kajpak o tem, kdo in kaj je veliki cesar bil za zahodne kristjane. In njihova presoja o njem se je zdaj seveda razlikovala od tiste njegovih sodobnikov, saj so se nekatere pri Evzebiju še samoumevne stvari že izkazale za iluzijo. Konstantinovi sinovi, v katere je škof iz Cezareje še lahko polagal upe, da bodo očetu podobni stebri Cerkve, pričakovanj ne le niso izpolnili, marveč se je eden med njimi, Konstancij II., v spomin zahodne krščanske javnosti za dolga stoletja celo zapisal kot krivoverec. S tem je sicer odpadel vmesni položaj vsakokratnega krščanskega cesarja med Bogom in Cerkvijo, ki se v Konstantinovih časih nikakor ni zdel možen samo Evzebiju, ${ }^{8}$ marveč tudi prenekateremu kristjanu na zahodu, a hkrati ni šlo brez vzvratnega vpliva na pojmovanje Konstantinove vloge, in to ne v zanj ugodni smeri.

Ob tem je potrebno priznati, da so silovitost konstantinskega preobrata vzhodni kristjani občutili veliko bolj, ker so na zahodu preganjanja zamrla vsaj že z Maksencijem, na Konstancijevem območju pa naj jih v znatnejšem obsegu sploh ne bi bilo (kot dovolj verodostojno poroča Laktancij). Hkrati je Licinij v času zaostrovanja z zahodnim vladarjem ponovno bolj pritisnil na Cerkev, čeravno ni moč govoriti o pravih preganjanjih. Zaradi povedanega je hvaležnost Konstantinu po 324 tudi bolj prišla do izraza in lahko precej dlje ostala v zavesti kristjanov. Očitno je - vsaj v večji meri ne - ni moglo zamegliti niti spoznanje, da po preobratu težav ni konec, pač pa so se v podobi teoloških sporov po nicejskem koncilu začeli povsem novi (kar so še predobro občutili in glasno povedali vsi zahodni krščanski zgodovinarji 4. in 5. stoletja).

Končno so tukaj nakazane razlike privedle do - kljub vsem upravičenim ugovorom ${ }^{9}$ vendarle dramatičnega - razkoraka v pojmovanju odnosov med Cerkvijo in državo. Pogledi na Konstantina so morali nujno slediti temu razvoju. Zato ni nič čudnega, da jo najbolje odnese ravno pri zgodovinarjih, ki sta veliko časa preživela na vzhodu, namreč pri Laktanciju (ki dolgo deluje v Nikomedeji in tam bržčas tudi napiše De mortibus) in pri Rufinu (ki kot menih živi v Egiptu in Palestini).

7 Njegovo vrednost poudarja Barnes 1973; podobno Edwards 1999, 271.

8 Zelo dobra analiza pri Bleckmann 1996, 97ss.; prim še Berkhof 1976, 32 in drugje.

9 Skrajno stališče je zastopal denimo Berkhof, o. c.; relativirata ga npr. Aland 1976 in Leppin 1996, predvsem 260-272. Literatura o tem vprašanju je kajpak nepregledna. 


\section{II}

Kar zadeva Laktancijev odnos do Konstantina, so bile bržkone preigrane že vse možnosti. Nekateri v njem vidijo enega glavnih Konstantinovih ideologov, nekakšnega zahodnega Evzebija ${ }^{10}$ drugi - prav nasprotno - menijo, da je bil cesar tisti, ki ga slutimo v ozadju teoloških pogledov »krščanskega Cicerona $\ll .{ }^{11}$ Tudi Laktancijev zgodovinski spis De mortibus persecutorum je pogosto veljal za izrazit odraz konstantinske propagande, ker naj bi njegov avtor veliko podatkov dobil od Konstantina samega. ${ }^{12} \mathrm{~A} \mathrm{k}$ temu se bom takoj vrnil.

Nedvomno je v Laktancijevem opusu najti mesta, na katerih prvi krščanski cesar nastopa v docela kanonizirani podobi. Predvsem gre tu za proslulo - na delo, končano že pred koncem preganjanj, pozneje prilepljeno - posvetilo (oziroma kar dve posvetili) v temeljnem retorjevem apologetskem besedilu Divinae institutiones. Tam nedvoumno beremo:

Quod opus nunc nominis tui auspicio incochamus, Constantine imperator maxime, qui primus Romanorum principum repudiatis erroribus maiestatem dei singularis ac veri et cognovisti et honorasti. Nam cum dies ille felicissimus orbi terrarum inluxisset, quo te deus summus ad beatum imperii columen evexit, salutarem universis et optabilem principatum praeclaro initio auspicatus es, cum eversam sublatamque iustitiam reducens taeterrimum aliorum facinus expiasti. Pro quo facto dabit tibi deus felicitatem, virtutem, diuturnitatem, ut eadem iustitia, qua iuvenis exorsus es, gubernaculum rei publicae etiam senex teneas tuisque liberis, ut ipse a patre accepisti, tutelam Romani nominis tradas. (Lact., Div. inst. 1,13s.).

Iz primerne časovne oddaljenosti, ki piscu omogoča, da stopi na grič in na zadeve pogleda v širšem kontekstu, se mu zdi Konstantinovo vladanje že od samega začetka velika sreča za ves svet, saj je dan Konstantinovega vzpona na prestol (ki ga sodobni zgodovinarji razglašajo za nič več in nič manj kot uzurpacijo ${ }^{13}$ ) označen kot dies ille felicissimus orbi terrarum. V najboljši maniri starorimskega teološkega kreda do, ut des (ki je šel tako v nos Berkhofu ${ }^{14}$ ) sodi, da bo Bog krščanskemu vladarju poplačal njegove usluge s srečo, ki se bo najprej odrazila v dolgem vladanju, nato pa - kar je morda še pomembneje - poskrbel, da bo prestol prešel na njegove telesne potomce. Slednji poudarek odraža dolgo monarhično izročilo pri kristjanih, saj se jim za razliko od nekaterih s

${ }^{10}$ Npr. De Palma Digeser 2000, po kateri naj bi Laktancij navdihnil cesarjevo tolerantno versko politiko.

${ }^{11}$ Najbrž najizraziteje Heim 1978.

${ }^{12}$ Izrazito Moreau 1954.

13 Odločno Brandt 2006, manj jasno Bleckmann 1996.

${ }^{14}$ Prim. Berkhof, o. c., passim, zlasti 26-28. 
senatnimi izročili prežetih poganov zdelo popolnoma samoumevno, da enemu Bogu ustreza (zgolj) en cesar, kar je skušal v apologetske namene uporabiti že Tertulijan ${ }^{15}$ (kajpak zgolj retorično uspešno), tovrstni opomini pa so se pomnožili po nastopu tetrarhov ${ }^{16}$ (in tu so se pogledi kristjanov bržčas staknili s Konstantinovimi $i^{17}$ ). Nič čudnega torej, da je postalo in ostalo vprašanje »nasledstva sinov« pomembno pri skoraj vseh krščanskih zgodovinarjih, tako pri Evzebiju na vzhodu (ki Vita Constantini napiše z mislijo na cesarjeve sinove) kot pri Rufinu, Oroziju in celo Avguštinu (vsaj v nekem obdobju) na zahodu. ${ }^{18}$

A če se Konstantin v poznih dodatkih k Divinae institutiones kaže v povsem evzebijevskih barvah, ni nujno, da je temu tako tudi v zgodnejšem spisu. Prevetritev vprašanja njegove datacije,${ }^{19} \mathrm{ki} \mathrm{ji} \mathrm{je} \mathrm{vrata} \mathrm{odprlo}$ drugačno datiranje nekaterih dogodkov iz politične zgodovine (zlasti Dioklecijanove smrti in bitke pri Cibalah), ${ }^{20}$ je postavilo pod vprašaj in zelo relativiralo prejšnja mnenja o De mortibus kot izključnem trobilu konstantinske propagande. Že Barnes je s tem v zvezi opozoril na s slednjo nezdružljiva prikaza cesarjev Maksimijana (ki jo resda odnese bolje kot Galerij, a nikakor ni na piedestalu, na kakršnem je bil po kratkem obdobju nemilosti kot oče cesarjeve žene Favste) in Maksencija (ki po drugi plati ni tiran do te mere, kot bi se Konstantinovemu krogu najbrž zdelo prav).$^{21}$ A ključna točka težavnosti retorjevega zgodovinskega delca je drugje.

Seveda sin Konstancija Klora že, ko se pojavi na sceni, nastopi v najlepši luči. Laktancij ga predstavi takole: Constantio quoque filius erat Constantinus, sanctissimus adulescens [podčrtal A. M.] et illo fastigio dignissimus, qui insigni et decoro habitu corporis et industria militari et probis moribus et comitate singulari a militibus amaretur, a privatis optaretur (DMP 18,10). Pozitivnost njegovega lika zasije še tem bolj, če ga primerjamo s piščevimi uvodnimi opazkami o nekaterih drugih akterjih takratnega dogajanja (npr. v neposredni soseščini - 18,9 - o Maksenciju, pozneje o Maksiminu Daji). Tudi pozneje na Konstantina ne pade nobena senca. Izkaže se za pokornega sina $(24,8)$ in prizanesljivega zeta, saj

\footnotetext{
${ }^{15}$ Recimo v Ad Scapulam 2,5.

${ }^{16}$ Čeprav De Palma Digeser 2000 gotovo pretirava, pomena »monarhističnih« pasusov v Divinae institutiones in v De mortibus gotovo ne gre podcenjevati.

${ }^{17}$ O Konstantinovem preziranju tetrarhije zdaj Brandt 2006, zlasti 32-37.

${ }^{18} \mathrm{~S}$ poudarkom na Rufinu, a tudi širše Molè Ventura 1989.

${ }^{19}$ Medtem ko sta Moreau 1954 in Prete 1956 De mortibus persecutorum postavljala še celo na začetek dvajsetih let 4. stoletja, danes komaj kdo dvomi o tem, da je spis nastal v prvih letih po Maksencijevem porazu; prim. denimo Creed 1984 ali nazadnje Winkelmann 2003.

${ }^{20}$ Ključen prispevek še vedno Barnes 1973.

${ }^{21}$ Barnes 1973, 41s.
} 
prvič odpusti Maksimijanu $(29,8)$. Barnesu ${ }^{22}$ se zdi posebej pomenljiva omemba njegovega domnevnega prvega dejanja po prevzemu oblasti: Suscepto imperio Constantinus Augustus nihil prius egit quam christianos cultui ac deo suo reddere. Haec fuit prima eius sanctio sanctae religionis restitutae $(24,9)$. Podpiranje krščanstva in kristjanov naj bi bilo v optiki dvornega učitelja iz Nikomedeje potemtakem od vsega začetka na samem vrhu Konstantinovih ukrepov, kar je kajpak dovolj blizu Evzebijevi liniji. V nadaljevanju »krščanski Ciceron « svoje videnje zadeve podkrepi še s pismom, ki naj bi ga Konstantin že pred dogovorom z Licinijem v Mediolanu poslal Maksiminu Daji in vsaj nekoliko obrzdal njegovo zoperkrščansko divjanje. Potem ko opiše zvito Maksiminovo ravnanje, saj kristjanov po Galerijevem tolerančnem ediktu ni več pobijal, jih je pa veselo dal pohabljati, opozori, da Haec ille [sc. Maximinus] Constantini litteris deterretur. Simulavit ergo $(37,1)$.

Konstantinov odnos do kristjanov je tedaj pri Laktanciju vseskozi jasen in enoznačen. Zanj je navsezadnje poplačan z Božjim opozorilom pred bitko pri Milvijskem mostu: Commonitus est in quiete Constantinus, ut caeleste signum dei notaret in scutis atque ita proelium committeret $(44,5)$. Kratkost pravkar navedenega opisa pa zbode v oči. Kaj je sploh bila vsebina videnja, izvemo šele, ko pisec poroča o cesarjevi izvršitvi navodila (ibidem). Po svoji stvarnosti Laktancijevo videnje dogodkov ob ključni bitki, ki naj bi po mnenju večine sodobnikov in poznejših razlagalcev pomenila osrednjo točko »konstantinskega preobrata «, ne odstopa bistveno samo od tistega, kar nam o isti temi pove Evzebij, ${ }^{23}$ marveč pri Laktanciju Konstantin nikakor ni edini, ki ima tovrstno videnje. Dve poglavji pozneje, pred bitko med Licinijem in Maksiminom Dajo, namreč beremo: Tunc proxima nocte Licinio quiescenti adstitit angelus dei monens, ut ocius surgeret atque oraret deum summum cum omni exercitu suo: illius fore victoriam, si fecisset $(46,3)$. Čeprav je opis nadvse podoben kot $v$ štiriinštiridesetem poglavju, izvemo vendarle za odtenek več podrobnosti (saj k vladarju vzhoda pristopi Božji angel). Bistveno več prostora pisec ravno tako nameni pripovedi o Licinijevi izpolnitvi angelovega naročila, ker v celoti navede molitev vojakov $(46,6)$. In tudi po bitki se Konstantinov sovladar ne izkaže nič manj pobožnega od njega: Licinius vero accepta exercitus parte ac distributa traiecit exercitum in Bithyniam paucis post pugnam diebus et Nicomediam ingressus gratiam deo, cuius auxilio vicerat, ac die Iduum Iuniarum Constantino atque ipso ter consulibus de restituenda ecclesia [...] litteras ad praesides datas proponi iussit $(48,1)$. Logična posledica pravkar povedanega je še, da sta oba vladarja

${ }^{22}$ Ibidem, 43. Brandt je do Laktancijevega poročila znova skeptičen.

${ }^{23} \mathrm{~Pa}$ najsi je bil škof iz Cezareje ob poročanju o vladarjevem videnju še v takšni zadregi, kot meni denimo Chesnut 1986, 172. 
enako zaslužna za zakonsko izenačitev krščanstva s poganstvom (ali bolje za uveljavitev verske svobode) s t. i. Milanskim ediktom.

Potemtakem ne gre za to, da bi bil retor iz Nikomedeje kritičen do prvega krščanskega cesarja; težava je, da ni (dovolj) kritičen do njegovega poznejšega nasprotnika Licinija. Ta poteza De mortibus je zmedla že poznejše rodove, ki so raje sprejeli Evzebijevo (črno-belo) različico dogodkov. ${ }^{24}$ Morda bi bilo drugače, ko bi Laktancij objavil še popravljeno in ažurirano izdajo svojega zgodovinskega dela, kakor je to storil z Divinae institutiones in kakor je storil cezarejski škof s svojo Cerkveno zgodovino. ${ }^{25}$

Kar je ostalo, je neposreden odmev na dogodke, po vsem videzu pisan z vidika kristjanov z vzhoda. Zanje je Licinijeva zmaga nad Maksiminom Dajo predstavljala bistveno pomembnejši prelom kot bitka pri Milvijskem mostu, saj Maksencij kot preganjalec kristjanov nikakor ni mogel soditi v isto vrsto z nekdanjim Galerijevim socesarjem. In temu ustrezno so postavljena razmerja med osebami in dogodki v $D e$ mortibus. Zgodovinska ironija, o kateri bo še kaj govora, je seveda, da se je Licinij kmalu spremenil v glavnega sovražnika Cerkve, kar je še kako odmevalo v izročilu, za izoblikovanje katerega so bili v naslednjih dveh desetletjih zaslužni vzhodni kristjani, ki so živeli pod Licinijevo peto, predvsem Evzebij. Le-ta je tako rekoč do konca svojega življenja ostal na tekočem, »krščanski Ciceron« pa je kristjanom naslednjih stoletij zapustil podobo, ki je bila aktualna le malo časa. $\mathrm{V}$ tej podobi je kljub vsem pomislekom mogoče videti Licinija kot enakovrednega Konstantinu ali celo kot glavni pozitivni lik v De mortibus, ${ }^{26}$ vsaj če primerjamo za kristjane ključna mesta v besedilu. Res je, da vladar vzhoda pri Laktanciju nima niti približno tako premočrtnega in brezgrajnega življenjepisa kot Konstantin (navsezadnje ga je na sceno pripeljal glavni preganjalec Galerij). Res je tudi, da bi opisovanje Licinijevega znašanja nad še živimi potomci tetrarhov lahko razumeli kot kritiko njegovega ravnanja. Toda ne gre pozabiti, da morajo biti po teologiji De mortibus preganjalci brezpogojno kaznovani, kar naj se pozna tudi pri njihovem potomstvu. S krvoločnostjo zmagovalca nad Maksiminom Dajo bi utegnil imeti težave šele Orozij, za Laktancijevo »pogansko hvalnico« triumfu krščanstva ${ }^{27}$ jih na tej točki ni.

$\mathrm{Na}$ ta način je edini latinsko pišoči Konstantinov sodobnik med krščanskimi zgodovinarji ustvaril izročilo, ki je imelo v marsičem drugačne

\footnotetext{
${ }^{24}$ Winkelmann 2003, 34.

${ }^{25}$ Nazadnje pregledno o izdajah HE Winkelmann 2003, 5 ss.; gl. denimo še Chesnut 1986, 114 ss.

${ }^{26}$ Izrecno A. S. Christensen 1980, 27 ss.

${ }^{27}$ Prim. Zecchini 1993, 16.
} 
poteze kot tisto na vzhodu. Čeprav ni lik prvega krščanskega cesarja v ničemer problematičen ali problematiziran, meče senco nanj že sama možnost, da bi mu bil kdo vsaj približno enak. Kajpak se Laktancijev spis (tudi) zaradi tega po priljubljenosti ni uspel kosati z Evzebijem (oziroma Rufinom, saj so zahodni kristjani »očeta cerkvene zgodovine« poznali zgolj v njegovi priredbi). Hkrati pa je manj povzdignjeno, celo nevtralno prikazovanje Konstantina ostalo stalnica pri vseh latinsko pišočih krščanskih zgodovinarjih - $\mathrm{z}$ izjemo Rufina - v naslednjih stotih letih. Čemur seveda ni v prvi vrsti botroval Laktancij, marveč zlasti drugačen - lažji - položaj kristjanov v zahodnem delu rimske države ob Konstantinovem nastopu, še bolj pa znabiti znotrajcerkvene in politične razmere pokonstantinskega časa, ki niso več dovoljevale evforije, kakršno sta si lahko privoščila Evzebij in Laktancij v Divinae institutiones. Povedano je slednjič na simbolni ravni pripomoglo, da Konstantin - kot že povedano - na zahodu kljub vsemu spoštovanju do svoje osebe ni dosegel časti oltarja.

\section{III}

Po De mortibus persecutorum na zahodu prav v času, ko ga avtor Cerkvene zgodovine in Vita Constantini uspešno kanonizira, krščanski pisci o Konstantinu molčijo. Kar je o njem povedanega v latinščini, izhaja izpod peresa poganov. Naslednje krščansko historiografsko pričevanje o njem izvira šele iz zgodnjih osemdesetih let 4 . stoletja in sodi v eno od velikih Hieronimovih podjetij, v njegovo Kroniko. Čeprav se je cerkveni učitelj iz Stridona menda resno ukvarjal z mislijo, da bi napisal obsežno cerkveno ali celo univerzalno zgodovino Orozijevega kova (kajpak s podloženo krščansko interpretacijo), kar je bil del programa njegovega sponzorja, papeža Damaza, ${ }^{28}$ je na celotno zahodno zgodovinopisje vplival predvsem s svojim prevodom in priredbo (z dopolnitvami do leta 378) Evzebijeve Kronike, ki ga je opravil okrog leta 380 in z njim na zahodu pometel s poprejšnjim kronografskim izročilom, temelječim na istovrstnem Hipolitovem delu in vidnim še v delu Kronografa iz leta $354 .{ }^{29}$

Konstantinova podoba je v Hieronimovem besedilu bistveno drugačna kot pri Laktanciju in pomeni najbrž največjo degradacijo cesarja v latinskem krščanskem zgodovinopisju pozne antike. Temu ne botruje le objektivni ton piščeve pripovedi, v kateri je nasploh malo privzdignjene govorice, marveč prejkone njegov nasploh odklonilni

\footnotetext{
${ }^{28}$ Gl. Zecchini 2003, 317.

${ }^{29}$ Ibid., 318.
} 
odnos do Konstantinove osebe. Ključ zanj je skrit v predzadnji s Konstantinom povezani notici, kjer je moč brati: Constantinus extremo vitae suae tempore ab Eusebio Nicomedensi episcopo baptizatus in Arianum dogma declinat, a quo usque in praesens tempus ecclesiarum rapinae et totius orbis est secuta discordia (Chron. ad a. 2353). Človeka, ki je v De mortibus označen z epitetom sanctissimus in ki naj bi po Divinae institutiones s svojim vzponom na oblast poskrbel za najsrečnejši dan svetovne zgodovine, Hieronim dobrega pol stoletja pozneje vsaj posredno šteje za krivca za to, da nesloga in druge tegobe, povezane $\mathrm{z}$ arijansko zmoto, trajajo še v njegov čas. Če je tako, do njega nikakor ni treba biti prizanesljiv niti ob prikazovanju drugih, poprejšnjih dogodkov.

Nič kaj obetaven ni že Konstantinov vstop v Kroniko. Pisec namreč doda nelaskavo podrobnost, o kateri Laktancij kajpak ne pove ničesar: Constantius XVI imperii anno obiit in Britannia Eboraci, post quem filius eius Constantinus ex concubina Helena procreatus [podčrtal A. M.], regnum invadit (ibid., ad a. 2322). Kaj naj od takega človeka pričakujemo? Hieronim ga sicer šteje za edinega pobudnika rehabilitacije kristjanov (ad a. 2330: Pax nostris a Constantino reddita) - Licinijev čas je pač že davno minil in v Kroniki večkrat dostojno konkurira velikim preganjalcem kristjanov - a na tej točki je pozitivnega hkrati že konec. S podtoni da prevajalec Svetega pisma v latinščino vseskozi vedeti, kaj si misli o nekdanji zvezdi svojih predhodnikov. Da bralec ne bi bil v zmoti, mobilizira celo osovraženega Licinija, ko se priduša nad Konstantinovo verolomnostjo (ki jo navsezadnje od krivoverca tudi pričakuješ): Licinius Thessalonicae contra ius sacramenti privatus occiditur (ad a. 2339). Konstantinove krvoločnosti pa še kar ni konec, saj se ne ustavlja niti pred umorom sina in nečaka, kar za nameček opravijo crudelissime (ad a. 2341); zanimivo je, da se ob poročanju o enaki Favstini usodi pisec kakršnemu koli sočutje zbujajočemu dostavku odreče.

A vtis je že dovolj močan. Od velikega Konstantina vzornika Evzebija ostane kaj malo. Najbrž so bili v času Hieronimovega pisanja Kronike še preveč živi spomini na nedavne ekscese cesarja Valenta, ko je arijanstvo (ali bolje tako imenovano arijanstvo) še zadnjič resno dvignilo glavo in ob tem so se morala $\mathrm{z}$ vso ostrino sprožiti tudi vprašanja o njegovih prvih letih. Od tod pa ni bilo več daleč do točke, ko je Konstantinova starostna zmota (to je bila z vidika katolikov, kajpak) prav zlahka zasenčila njegove zasluge, do katerih državljani tako ali drugače krščanskega cesarstva niso imeli več spoštljivega odnosa cesarjevih sodobnikov. Hieronimove ostrine poznejši krščanski zgodovinarji sicer niso več ponovili, je pa zelo odmevala vsaj pri Oroziju. 
Da je bila zadeva s Konstantinovimi verskimi zagatami na prelomu 4. in 5. stoletja še kako pereča, vsaj per negationem potrjuje prvemu krščanskemu cesarju najbolj naklonjeni zahodnjak med zgodovinarji. Gre za Rufina iz Konkordije, ki mu sicer še na misel na pride, da bi s Hieronimovim podobnimi poudarki blatil spomin na vladarja, a se mu zdi vendarle potrebno na nekaj mestih opozoriti, da stvari niso takšne, kot bi se utegnile komu po nemarnem zdeti.

A pojdimo po vrsti. Čeravno je Rufin pisal latinsko, je velik del svojega življenja prebil na vzhodu, kar ni pustilo sledi le v njegovi bogati prevodni dejavnosti (o kakovosti katere so mnenja še vedno zelo deljena $^{30}$ ), marveč tudi v tem, kako postavlja stvari v svojem najvplivnejšem delu - dveh knjigah dodatka k Evzebijevi Cerkveni zgodovini, ${ }^{31}$ ki ga je Duval krstil kar za »zahodni zgodovinski brevir, ${ }^{32}$ « čemur je moč samo pritrditi. ${ }^{33}$

Zato nikakor ni nepomembno, kaj Rufin pove o Konstantinu. Kot že nakazano, na nobeni točki ne sledi Hieronimovemu odnosu do njega. Prej verjetno soglaša z Laktancijevo mislijo, da je s Konstantinom nastopilo srečno obdobje zgodovine. Kot se spodobi najbolj pobožnemu med krščanskimi zgodovinarji, ki vseskozi daje vedeti, da piše »sveto zgodovino ${ }^{34}$ pa se obzorje cesarjeve izjemnosti hkrati pomembno zoži. Če Laktancijev katalog njegovih kreposti (prim. zgoraj navedeni odlomek!) še obsega vrsto »civilnih« odlik, nastopa Konstantin v Rufinovih dveh knjigah skoraj izključno kot pobožen kristjan. To je bil seveda že pri retorju iz Nikomedeje, a obenem je bil tam lahko še uspešen vojskovodja ali dober strateg (po drugi strani pri Hieronimu v Kroniki tako rekoč ni govora o njegovem krščanstvu).

Celo kot kristjan je zdaj cesar drugačen kot v Evzebijevih slavilnih spisih. Pri Rufinu ni občutka o njegovem nad Cerkvijo (ali vsaj nad škofi) privzdignjenem položaju ali pa se ta pojavlja le v zelo omejenem obsegu. Ključna s tem povezana mesta najdemo v Rufinovi pripovedi

${ }^{30}$ Pri Winkelmann 1965 tako skoraj zaslutimo hieronimovske tone, ko govori o Rufinu, drugi, kot že Oulton 1929 ali T. Christensen 1989, so mu bolj naklonjeni.

${ }^{31}$ Tudi ta dodatek so mu sicer odrekali in ga pripisovali skrivnostnemu Gelaziju iz Cezareje, o katerem pa je znano komaj kaj. Dobra povzetka spora o odnosu med obema piscema prinašata Van Deun 2003, 152-158, in Rohrbacher 2002, 100-101. Med novejšimi raziskovalci je do Rufinovega avtorstva najbolj skeptičen Winkelmann 1965, zlasti 70-102, medtem ko ga že s skoraj apologetsko vnemo brani Thelamon 1981; gl. tudi Schamp 1987.

${ }^{32}$ Navedeno po Van Deun 2003, 166.

${ }^{33} \mathrm{~V}$ zvezi s tem naj opozorim samo na dosledno upoštevanje Rufinovega dela v romanu Skušnjava svetega Antona francoskega realista Flauberta.

${ }^{34}$ Kot vseskozi poudarja Thelamon 1981. 
o nicejskem koncilu. Konstantin je tisti, ki koncil skliče (a že omenjeno stori ex sententia sacerdotum; HE 10,1). Na njem ima (po Rufinovo) pomemben govor, $\mathrm{v}$ katerem okrca spore in prepirljivost škofov:

Cum ex omnibus paene locis episcopi convenissent et, ut fieri solet, diversis ex causis inter se quaedam iurgia detulissent, interpellebantur frequenter a singulis [...] et magis ad haec, quam ad id, pro quo ventum fuerat, animos dabant. At ille videns, quod per huiusmodi iurgia causa summi negotii frustratretur, diem certam statuit, qua unusquisque episcoporum, si quid caerimoniae habere videretur, deferret. Et cum resedisset, suscepit a singulis libellos. [...] Ad episcopos ait: »Deus vos constituit sacerdotes et potestatem vobis dedit de nobis quoque iudicandi, et ideo nos a vobis recte iudicamur, vos autem non potestis ab hominibus iudicari. Propter quod dei solius inter vos expectate iudicium et vestra iurgia, quaecumque sunt, ad illud divinum reserventur examen.« (HE 10,2).

V odlomku Konstantin jasno prizna, da ne more soditi škofom, medtem ko je obratno mogoče. To priznanje je prvo spričevalo njegove pobožnosti; drugo je njegova vnema za resnično pomembne naloge koncila, ki se dvigajo visoko nad malenkostne spore škofov (le-ti so deležni kritike zgodovinarja iz Konkordije še na mnogih drugih mestih). Marsikdo bi se utegnil seveda vprašati, ali ni spričo pravkar povedanega krščanski cesar vendarle postavljen nad škofe. Odgovor bi morda lahko bil sicer tudi pritrdilen, a s pomembnim pristavkom, da je nadnje v Rufinovih očeh postavljen ne kot posvetni vladar, ampak kot vzoren kristjan; tako se nič ne razlikuje od preprostega pričevalca, ki v naslednjem poglavju s svojo pristno vero spreobrne učenega filozofa.$^{35}$ Vrhu tega svojo podložnost škofom cesar še stopnjuje s precej skrajno izjavo, da Conveniens non est, ut homo iudicet deos, sed ille solus, de quo scriptum est: deus stetit in congregatione deorum, in medio autem deos discernit..$^{36}$ Končno sledi v četrtem poglavju še praktična potrditev, ko cesar egiptovskemu škofu Pafnuciju kar naprej poljublja med Maksiminovim divjanjem proti kristjanom iztaknjeno oko (kar je neznansko zabavalo Flauberta).

Podobo Konstantinove krščanske vneme še dopolnjujejo pobožna dejanja njegove matere Helene (kajpada ni nič govora o tem, da bi bila concubina), še zlasti odkritje Odrešenikovega križa (plastični opis v $H E 10,8)$.

Tema, ki ji Rufin med vsemi krščanskimi zgodovinarji posveča največ prostora, je širjenje Cerkve izven meja rimske države. Kot edini poroča o prodoru krščanstva v oddaljene predele, kot sta bila Etiopija

\footnotetext{
${ }^{35} \mathrm{Na}$ značilno potezo Rufinove teologije zgodovine, da namreč izjemni verniki po pomenu presegajo pripadnike uradne hierarhije, opozarja že Thelamon 1992.

${ }^{36}$ Navedek je Ps 81,1 .
} 
in današnja Gruzija. ${ }^{37} \mathrm{~V}$ okviru te razprave nas podrobnosti omenjenih mest ne zanimajo, potrebno je samo opozoriti, da je konkordijski teolog omenjene akcije (najbrž namerno) prestavil iz obdobja (sumljivega) cesarja Konstancija II., ko je do njih v resnici prišlo, v obdobje njegovega očeta, svojega junaka. ${ }^{38}$

Podobno se je znašel ob tistem vprašanju, ki je kristjane ob koncu 4. stoletja v zvezi s Konstantinom najbolj mučilo in Hieronimu narekovalo njegovo negativno sodbo o cesarju. Za Rufina je bil položaj še toliko težavnejši, ker je že Konstantin po sinodi v Tiru leta $335^{39}$ izgnal v Trevere Atanazija, osrednjo cerkvenopolitično osebo druge polovice desete knjige Cerkvene zgodovine.

Da bi najprej omilil učinek Hieronimove sodbe o cesarju kot arijanskem krivovercu, je posegel po večkrat uporabljenem sredstvu zgodovinarjev. Krivdo za ponovni vzpon arijancev in za Arijevo rehabilitacijo na dvoru je pripisal duhovniku, ki ga je svojemu cesarskemu bratu priporočila Licinijeva vdova Konstancija: Constantia tunc Licinii relicta fratris Augusti solaciis utebatur. Huic accidit presbyterum quendam venire in notitiam latenter partibus Arrii faventem. [...] Quae [sc. Constantia] cum diem obitura visitaretur a fratre atque ab eo blande religioseque compellaretur, extremam dicitur ab eo gratiam poposcisse, ut presbyterum in familiaritatem reciperet; [...] se quidem iam ex luce discedentem nihil curare, pro fratris vero statu esse sollicitam, ne forte pro innocentium poenis regni sui pateretur excidium $(H E 10,12)$. Ženskam na dvoru so tako krščanski kot poganski historiografi radi pripisovali krivdo za (po mnenju piscev) napačen razvoj dogodkov. ${ }^{40}$ Iz varnostnih razlogov je avtor latinske Cerkvene zgodovine še preskočil omembo cesarjevega krsta in se zadovoljil zgolj z opozorilom na to, da je Konstantin duhovnika, ki mu ga je priporočila sestra, postavil za izvršitelja svoje oporoke.

Še zahtevnejša je bila naloga s sinodo v Tiru. Tu piscu ni preostalo drugega, kot da jo je premaknil v čas vladanja Konstancija II., o katerega hoji po stranpoteh ni bilo dvoma že od samega začetka, čeprav v Rufinovi optiki tudi tu ni moglo biti drugače, kakor da je bil Konstantinov sin zapeljan (krivci so bili arijanstvu naklonjeni evnuhi; prim. 10,12 in 10,16). Zaradi tega naj bi po Rufinovo sploh sklical tirsko sinodo.

V celoti gledano je Rufin dokaj spretno sledil svojemu namenu pri prikazovanju Konstantinovega lika in na zahodu uveljavil povsem drugačno gledanje na cesarja, kot je bilo Hieronimovo. Ker je bil Evzebijev prevajalec izjemno bran, njegovi pogledi nikakor niso ostali brez

\footnotetext{
${ }^{37}$ Vrednost Rufinovih opisovih zlasti poudarja Thelamon 1981.

${ }^{38}$ Rohrbacher 2002, 103.

${ }^{39} \mathrm{O}$ njej in Atanazijevem prvem izgonu dobro Cedilnik 2004, 50-70.

${ }^{40}$ Leppin 2003, 105.
} 
vpliva, vendar bolj v poznejših stoletjih kot pri zgodovinarjih naslednjih desetletij. Po eni strani je temu botroval drugačen položaj po gotskem zavzetju Rima leta 410, ko zgolj tolažilni toni, na katere je - kot pravi že v predgovoru - stavil Rufin, pri pisanju zgodovine niso bili dovolj, po drugi strani pa je naredil nekaj podobnega kot Laktancij, ki je Konstantinu ob bok postavil Licinija; Rufin je še bolj kot Konstantina povzdignil kajpak svojega sodobnika Teodozija.

Padec Rima 410 je, kot je znano, navdihnil dve za krščansko razumevanje zgodovine ključni besedili, najprej najtemeljitejši prikaz teologije zgodovine v Avguštinovem Božjem mestu, nato pa še sprva kot dopolnilo prvemu mišljeno krščansko interpretacijo celotne svetovne zgodovine v Orozijevi Zgodovini proti poganom. Slednja je bila edini resni poskus kakega krščanskega pisca po Laktanciju, da bi tekmoval s poganskimi kolegi na polju posvetne zgodovine. Obenem pa je duhovnika iz Brakare vodil očiten apologetski namen, saj je po Avguštinovih navodilih $\mathrm{v}$ svetovni zgodovini iskal predvsem dokaz za svojo temeljno tezo, da so krščanski časi srečnejši od poprejšnjih. S tistim, kar je nastalo, avtor Božjega mesta po uveljavljenem mnenju ni bil zadovoljen in Orozija ni v Božjem mestu nikjer izrecno omenil, ostro pa je kritiziral nekatere njegove poudarke (predvsem shemo desetih preganjanj). ${ }^{41}$ Glavni razlog za razlike med njima je bil bržčas njun različen odnos do rimskega imperija, kot jima ga je narekoval premislek o katastrofi gotskega sacco di Roma. Orozij je vztrajal pri domoljubnem optimizmu in veri v tempora Christiana, Avguštin ne. ${ }^{42}$

Osnovna Špančeva perspektiva je odločilno vplivala na njegovo sliko prvega krščanskega cesarja; morda so k njej prispevali tudi intenzivni stiki s Hieronimom v Palestini. ${ }^{43} \mathrm{Na}$ prvi pogled je Orozijev Konstantinov lik najbolj brezbarven v celotni krščanski poznoantični histroriografiji. Pozitivni toni so dokaj blagi, po drugi strani pa ni omembe njegovih domnevnih verskih stranpoti. Orozij mu v dobro vsekakor šteje, da je bil primus imperatorum Christianus excepto Philippo (Or., $7,28,1)$, na več mestih prav tako pohvali njegovo uspešno vladanje (že v 7,28,5: Constantino in Gallis strenuissime rempublicam procurante praetoriani milites Romae Maxentium, filium Herculii, [...] Augustum nuncupaverunt) in

\footnotetext{
${ }^{41}$ Npr. Zecchini 1987, 50-60; Tanz 1983.

${ }^{42}$ Čeprav za omenjeno vero poprej nikakor ni bil nedovzeten: Markus 1989, zlasti $22-44$.

${ }^{43} \mathrm{O}$ teh stikih denimo Rohrbacher 2002, 136 s.
} 
poudari, da je rimsko cesarstvo $\mathrm{v}$ zadovoljivem stanju izročil sinovom (Cumque bellum in Persas molliretur, in villa publica iuxta Nicomediam, dispositam bene rempublicam filiis tradens, diem obiit; 7,28,31). Hkrati kot Hieronim - in v očitnem nasprotju z Rufinom - navaja večino spornih Konstantinovih dejanj, z izjemo domnevnega krivoverstva. Odpove se tudi negativnim oznakam teh dejanj, kot jih je rabil pisec iz Stridona. Ko govori o usmrtitvi Licinija, izpusti omembo prelomljene prisege in dejanje opravičuje s svarilnim zgledom vladarjevega tasta Maksimijana $(7,28,20)$. Ravno tako skoraj ne komentira obračuna s sinom in nečakom, ko pravi: Sed inter haec latent causae, cur vindicem gladium et destinatam in impios punitionem Constantinus imperator etiam in proprios egit affectus. Nam Crispum, filium suum, et Licinium, sororis filium, interfecit $(7,28,26)$. Omembe vredno je še Špančevo poudarjanje krščanske narave Konstantinove nove vzhodne prestolnice, saj naj bi bila expers idolorum; nekaj podobnega je zatrdil tudi Avguštin.

V skupnem seštevku bi bilo bržčas moč pritrditi Rohrbacherju, da je Konstantin v Historiae adversus paganos sicer pozitivna oseba, da pa njegovo vladanje nikakor ne pomeni pomembnejše prelomnice $\mathrm{v}$ Orozijevi viziji zgodovine, ${ }^{44}$ česar ne razbiramo le, če ga primerjamo s prikazom cesarja Teodozija, ki mora biti že po logiki dela srečnejši in boljši cesar od predhodnika (zlasti v kričečem nasprotju s Konstantinovimi krvoločnimi podvigi je poudarjanje Teodozijevih nekrvavih zmag, ko je vojna pravzaprav mir $^{45}$ ), marveč - in to na Konstantina meče še bolj čudno luč - tudi ob premisleku o Orozijevi upodobitvi prvega rimskega cesarja. Tam je prelomni značaj njegove vlade docela jasno izražen in podkrepljen z znamenito mistifikacijo, ko prezbiter namerno pomeša tri ključne dogodke Oktavijanove vladavine (pridobitev naslova Avgust, zaprtje Janusovega svetišča in triumf nad vzhodom) in vse datira na 6 . januar (dan Kristusovega razodetja) 29 pr. Kr. Če je treba izbrati med Hieronimom in Rufinom, je Orozij v svojem odnosu do Heleninega sina nedvomno bližji prvemu. Nenazadnje tudi v tem, da skoraj nič ne govori o vladarjevem krščanstvu.

\section{VI}

Podobno dvoumno je dejansko stanje, ki se skriva za pozitivno fasado kratkega Konstantinu posvečenega poglavja v peti knjigi Avguštinovega Božjega mesta $(C D 5,25)$. Seveda - hiponski škof priznava, da je Konstantin, ki ni častil demonov, dolgo vladal kot edini vladar in po

${ }^{44}$ Ibidem, 144; podobno Zecchini 2003, 325.

${ }^{45}$ Zecchini 2003, 326. 
smrti v visoki starosti zapustil prestol sinovom (kar je bilo za kristjane, kot nekje povedano, izjemno pomembno). Nekoliko nenavadno je znabiti, da najprej omeni ustanovitev Konstantinopla, ki mu pripiše Orozijevim podobne atribute: Cui [sc. Constantino] etiam condere civitatem Romano imperio sociam, velut ipsius Romae filiam, sed sine aliquo daemonum templo simulacroque concessit.

Dvome o iskrenosti takšne fasade zbuja že Avguštinov odnos do rimskega cesarstva in njegovih cesarjev, kot diha iz celotnega Božjega mesta in o čemer na tem mestu ne bi posebej govoril. Res je sicer, da sodi evlogij Konstantinu v eno od zgodnejših knjig, ko najbrž še ni prišlo do spremembe perspektive (in še večjega odmika od poveličevanja Rima kot krščanskega imperija), značilne za drugo polovico dela. ${ }^{46}$ Še bolj se pomnožijo, če bralec samo na kratko poškili v sosednje, Teodoziju posvečeno poglavje. Evlogij zadnjemu vladarju celotnega cesarstva ni samo bistveno daljši, marveč je tudi vsebinsko povsem drugačen. Kot deloma že pri Rufinu in še veliko bolj pri Oroziju so Teodozijeve krščanske vrline precej bolj poudarjene. Navsezadnje je cesar zanje poplačan s čudežno zmago pri Frigidu.

Slednjič je potrebno upoštevati drugi del »Konstantinovega poglavja « v De civitate Dei. Tam beremo, da krščanskega vladarja nikakor ne bomo prepoznali po obsegu njegove zemeljske sreče. Avguštin dobesedno pravi: Sed rursus ne imperator quisquam ideo Christianus esset, ut felicitatem Constantini mereretur, cum propter vitam aeternam quisque debeat esse Christianus: Iovianum multo citius quam Iulianum abstulit; Gratianum ferro tyrannico permisit interimi, longe quidem mitius quam magnum Pompeium in colentem velut Romanos deos $(C D 5,25)$. Komaj se je tedaj moč ubraniti občutka, da je v Afričanovem prikazu Konstantinove sreče vsaj kakšna kaplja ironije. Kolikor cesarja že povzdigne, je to zgolj v službi protipoganske polemike na prvo žogo, češ, da ne bo videti, kot da so z obiljem in dolgim življenjem obdarjeni samo najbolj zakrknjeni častilci starih bogov (odmevi te na trenutke dokaj popreproščene argumentacije so posejani povsod po prvih knjigah Božjega mesta, najdemo jih tudi ob omembi Pompeja Velikega na navedenem mestu). Atributi Konstantinovega vladanja pa sicer v Hipončevi perspektivi niso nekaj, po čemer bi moral hrepeneti resnični krščanski vladar. Avguštinov Konstantin tedaj znova - kot pogosto $\mathrm{v}$ zahodni krščanski historiografiji iz pozne antike - deluje nekako - pogansko.

Ob kratki predstavitvi nekaterih značilnih odlomkov iz besedil izbranih zgodovinarjev je postalo precej jasno, da Konstantin na zahodu v 4. in 5. stoletju ni užival nedeljene in vsepričujoče naklonjenosti. Čeravno sta oba skrajna glasova, glasova starih nasprotnikov Rufina

${ }^{46}$ D'Elia 1980, 401. 
in Hieronima, ostala sorazmerno osamljena, bi bilo moč celo trditi, da je bila Hieronimovo videnje Konstantinovega lika neposrednim naslednjim rodovom bližja, pač v prvi vrsti zato, ker na zahodu niso v tolikšni meri občutili rešilnega pomena Konstantinove spreobrnitve in ker so na drugi strani boleče občutili homatije $\mathrm{z}$ arijanci, za katere je prevajalec Vulgate krivil prav prvega krščanskega cesarja. Novo obdobje v recepciji njegove osebe se je začelo šele, ko sta svoj pohod začeli Silvestrova legenda in $\mathrm{z}$ njo tesno povezana $\gg$ Konstantinova darovnica $\ll .{ }^{47}$

\section{LITERATURA}

ALAND, K.: Kaiser und Kirche von Konstantin bis Byzanz. Die Kirche angesichts der Konstantinischen Wende (ed. G. Ruhbach). Darmstadt 1976. 42-73.

BARCELO, P.: Constantius II. und seine Zeit: Die Anfänge des Staatskirchentums. Stuttgart 2004.

BARNES, T.: Lactantius and Constantine. fRS LXIII (1973). 29-46.

BERKHOF, H.: Die Kirche auf dem Wege zum Byzantinismus. Die Kirche angesichts der Konstantinischen Wende (ed. G. Ruhbach). Darmstadt 1976. 22-41.

BLECKMANN, B.: Konstantin der Grosse. Reinbek bei Hamburg 1996.

BRANDT, H.: Konstantin der Grosse: Der erste christliche Kaiser. München 2006.

CEDILNIK, A.: Ilirik med Konstantinom Velikim in Teodozijem Velikim. Ljubljana 2004.

CHESNUT, G. F.: The First Christian Histories. Macon 1986.

CHRISTENSEN, A. S.: Lactantius the Historian. Copenhagen 1980.

CHRISTENSEN, T.: Historia ecclesiastica. Copenhagen 1989.

CREED, J. L.: Introduction. Lactantius: De mortibus persecutorum. Oxford 1984. xv-xlvii.

D'ELIA, S.: Storia e teologia della storia nel De civitate Dei. La storiografia ecclesiastica nella tarda antichità (ed. S. Calderone). Messina 1980.

DEMANDT, A.: Geschichte der Spätantike. München 1998.

DE PALMA DIGESER, E.: The Making of a Christian Empire: Lactantius \& Rome. Ithaca-London 2000.

EDWARDS, M.: The Constantinian Circle and the Oration to the Sain-

${ }^{47} \mathrm{Na}$ kratko npr. Schimmelpfennig 2005, 95s. 
ts. Apologetics in the Roman Empire (ed. M. Edwards et al.). Oxford 1999. 251-275.

GIRARDET, K. M.: Die Konstantinische Wende: Voraussetzungen und geistige Grundlagen der Religionspolitik Konstantins des Grossen. Darmstadt 2006.

HEIM, F.: L'influence exercée par Constantin sur Lactance: sa théologie de la victoire. Lactance et son temps: Recherches actuelles (ed. J. Fontaine in M. Perrin). Pariz (Paris) 1978. 55-70.

LEPPIN, H.: Von Constantin dem Grossen zu Theodosius II.: Das christliche Kaisertum bei den Kirchenhistorikern Socrates, Sozomenus und Theodoret. Göttingen 1996.

LEPPIN, H.: Theodosius der Grosse: Aufdem Weg zum christlichen Imperium. Darmstadt 2003.

MARKUS, R. A.: Saeculum: History and Society in the Theology of St. Augustine. Cambridge 1989. ${ }^{2}$

MOLE VENTURA, C.: Teologia politica e successione dinastica nella Historia ecclesiastica di Rufino d'Aquileia. Studi tardoantichi VI (1989). 201-243.

MOREAU, J.: Introduction. Lactance: De la mort des persecuteurs I. Pariz (Paris) 1954 (SC, 39).

OULTON, J. E. L.: Rufinus's Translation of the Church History of Eusebius. FTS XXX (1929). 150-174.

PRETE, S.: Der geschichtliche Hintergrund zu den Werken des Laktanz. Gymnasium 63 (1956). 486-509.

ROHRBACHER, D.: The Hustorians of Late Antiquity. London-New York 2002.

SCHAMP, J.: The Lost Ecclesiastical History of Gelasius of Caesarea (CPG, 3521): Towards a Reconsideration. The Patristic and Byzantine Review 6 (1987)/2. 146-152.

SCHIMMELPFENNIG, B.: Das Papsttum: Von der Antike bis zur Renaissance. Darmstadt 2005. ${ }^{5}$

TANZ, S.: Orosius im Spannungsfeld zwischen Eusebius von Caesarea und Augustin. Klio 65 (1983)/2. 337-346.

THELAMON, F.: Païens et chretiens au IVe siecle: L'apport de l'Histoire ecclésiastique de Rufin d'Aquilée. Pariz (Paris) 1981.

THELAMON, F.: Apôtres et prophètes de notre temps: Les evêques et les moines presentés comme apôtres et prophètes contemporains dans l'Histoire ecclésiastique de Rufin. Storia ed esegesi in Rufino di Concordia. AAAD XXXIX (1992). 171-198.

VAN DEUN, P.: The Church Historians after Eusebius. Greek and Roman Historiography in Late Antiquity: Fourth to Sixth Century (ed. G. Marasco). Leiden-Boston 2003. 151-176. 
WINKELMANN, F.: Untersuchungen zur Kirchengeschichte des Gelasios von Kaisareia. Sitzungsberichte der Deutschen Akademie der Wissenschaften zu Berlin: Klasse für Sprachen Literatur und Kunst. 1965,3. Berlin 1966.

WINKELMANN, F.: Historiographie. $R A C X V$. 724-765.

WINKELMANN, F.: Historiography in the Age of Constantine. Greek and Roman Historiography in Late Antiquity: Fourth to Sixth Century (ed. G. Marasco). Leiden-Boston 2003. 3-39.

ZECCHINI, G.: Barbari e Romani in Rufino di Concordia. Rufino di Concordia e il suo tempo II. AAAD XXXI (1987). 29-60.

ZECCHINI, G.: Richerche di storiografia Latina tardoantica. Rim (Roma) 1993.

ZECCHINI, G.: Latin Historiography: Jerome, Orosius and the Western Chronicles. Greek and Roman Historiography in Late Antiquity: Fourth to Sixth Century (ed. G. Marasco). Leiden-Boston 2003. 317-345.

\section{Qui primus Romanorum principum maiestatem Dei singularis ac veri cognovisti: Einige Überlegungen zum Konstantinbild bei lateinischen christlichen Geschichtsschreibern des}

\section{4. und 5. Jahrhunderts \\ Zusammenfassung}

Obwohl Konstantin als der erste christliche Kaiser im Bewusstsein der Christen seit Jahrtunderten einen besonderen Platz eingenommen hat, sind dabei trotzdem einige nicht notwendig geringe Unterschiede zwischen der West- und Ostkirche zu beobachten. Die kommen symbolisch in der Tatsache zum Ausdruck, dass im Westen Konstantin niemals als Heiliger verehrt wurde, was auch die zu Teil stürmische Kritik an seine Person seit der Aufklärung erleichterte.

Der Autor mochte in diesem Aufsatz die Frage beantworten, wie es mit dem Konstantinbild in der frühesten Geschichtsschreibung der Westkirche steht. Zu diesem Zweck analysierte er einige typische Konstantinstellen bei Laktanz, Hieronymus in seiner Chronik, Rufin von Concordia, Orosius und schliesslich auch das Konstantineulogium in De civitate Dei Augustins. Dabei zeigte sich, dass lediglich Rufin in seiner, von östlichen Einflussen stark geprägten Kirchengeschichte dem östlichen Eusebianischen Model treu folgte und den Kaiser in erster Reihe als vorbildlichen Christen, dem der Fortschritt des christlichen Glaubens alles bedeutet, schilderte. Alle andere herangezogenen Ge- 
schichtsschreiber zeigen zu Teil erhebliche Abweichungen davon, die meist auf Grund der kirchenpolitischen Zusammenhänge, in denen sie wirkten, verstanden werden können.

Das trifft schon für das Konstantinbild bei Laktanz zu. Konstantin in De mortibus persecutorum ist zwar makellos und vom Anfang an ein grosser Befürworter des Christentums, muss sich jedoch auf Grund der frühen Entstehungszeit der Schrift unmittelbar nach der Konstantinischen Wende seinen erhobenen Platz mit seinem Mitkaiser Licinius teilen, was bei den Lesern aus den späteren Jahrhunderten für Verwirrung sorgte.

Ganz anders stehen die Dinge bei Hieronymus. Er macht Konstantin für die Ausbreitung des Arianismus verantwortlich, was alle seine Erfolge überschattet und in einem düsteren Bild des ersten christlichen Kaisers resultiert, wobei alle seine problematischen Taten Erwähnung finden, sein Christentum dagegen kaum.

Auch Orosius übernimmt die gerade erwähnten Taten in seine Erzählung, entschärft jedoch das negative Urteil des Hieronymus über Konstantin. Zugleich lässt er den Kaiser jedoch nicht nur weit hinter dem vorbildlichen Kaiser Theodosius, sondern auch hinter dem ersten römischen Kaiser Augustus stehen.

Augustinus schliesslich betonte zu einem das Glück Konstantins in allen Bereichen, was er auf sein Christentum zurück führt, da er keine Götzen verehrt habe, was jedoch im krassen Gegensatz zu seiner Behauptung, das irdische Glück könne nicht als Massstab des christlischen Herrschers gelten, steht, und somit das Konstantineulogium wenigstens zweideutig erscheinen lässt.

Naslov:

Aleš Maver

Fram $78 a$

SI-2313 Fram

e-mail:ales_maver@yahoo.com 